\title{
Manifestations of Aggression in the Adolescent Environment
}

\author{
Vladimir S. Sobkin, Ekaterina A. Kalashnikova \\ and Aleksandra V. Fedotova* \\ Center for Sociology of Education \\ Institute of Education Management \\ of the Russian Academy of Education \\ Moscow, Russian Federation
}

Received 20.01.2020, received in revised form 24.01.2020, accepted 07.02.2020

\begin{abstract}
The article discusses the peculiar features of physical aggression among adolescents and the main motives that encourage them to resort to violence. It is based on the materials obtained by the researchers of the Center for Sociology of Education of the Institute of Education Management of the Russian Academy of Education in the course of an anonymous questionnaire survey of 2983 students in grades 7, 9 and 11 of Moscow schools.

The analysis of the influence of gender, age, and social stratification factors reveals motivational dominants that determine the characteristic features of the adolescents' participation in fights depending on gender and age.

Special focus is given to physical aggression in the walls of an educational organization, and namely the prevalence of fights on school grounds and the adolescents' opinions about their teachers' reactions to fights between their students.

A fairly high level of prevalence of fights among girls indicates a significant deformation of traditional gender-role behaviors in the adolescent subculture.

The research results in the conclusion that manifestations of physical aggression are related to both social mechanisms of the adolescent subculture functioning and mental characteristics of adolescence.
\end{abstract}

Keywords: physical aggression, adolescent, socialization, motivation to participate in fights, gender specificity, social stratification factors, school as a social institution.

Research area: social sciences.

Citation: Sobkin, V.S., Kalashnikova, E.A., Fedotova, A.V. (2020). Manifestations of aggression in the adolescent environment. J. Sib. Fed. Univ. Humanit. Soc. Sci., 13(2), 234-245. DOI: 10.17516/1997$1370-0554$.

\footnotetext{
(C) Siberian Federal University. All rights reserved

* Corresponding author E-mail address: sobkin@mail.ru, 5405956@mail.ru, alexandrafedotova@rambler.ru ORCID: 0000-0002-2339-9080 (Sobkin); 0000-0003-4429-623X (Kalashnikova); 0000-0003-4960-8183 (Fedotova)
} 


\section{Introduction}

Manifestations of physical aggression are given special attention in the research works about various forms of deviant behaviour in adolescence. A number of fundamental studies, both domestic and foreign, cover this issue (Bandura, Uoters, 2000; Kon, 1979; Green, Feshbach, 1971; Slovák, 2015; Tedeschi et al., 1974 et al.). They highlight various aspects related to adolescent aggression: the prevalence of various types of aggression in the adolescent environment (Lipskaia, 2019; Sheveleva, 2006), age (Lebedeva, 2019) and gender (Baryshnikova, 2012) features of aggression, the influence of media and social networks (Zhmurov, 2007; Sobkin, Fedotova, 2019), regional factors (Mantrova, Skakun, 2015) and the type of educational institution (Chepeleva, 2002), and social status in the classroom (Koloiartseva, 2016).

Special focus is given to the prevention of adolescent aggressive behaviour (Dashieva, Budaeva, 2019). In this regard, it is also worth while noting the cycle of our research works on the teachers' perception of adolescent aggression (Sobkin, Fomichenko, 2011, 2012a, 2012b).

This article is devoted to the analysis of peculiar features of physical aggression among adolescents. It is based on the materials of a questionnaire survey of 2,983 students in grades 7, 9 and 11 of Moscow secondary schools.

The empirical material is grouped as per the following three content sections: the prevalence of fights among students; motives of physical aggression; and physical aggression between students on school grounds.

The obtained data are analyzed in relation to the influence of age, gender, and social stratification factors. In the course of interpreting the results special attention is paid to peculiar features of masculine and feminine attitudes manifestation in the adolescent subculture.

Moreover, taking into account the peculiar features of adolescence, manifestations of physical aggression are viewed as special indicators that determine different trajectories of socialization, the trajectories being associated with stylistic features of behaviour both in situations of current microsocial environment and in situations of "social environment expansion". In this regard, it is particularly important to take into account social stratification factors (the family's financial situation and the parents' education level). This allows us to clarify the content features of the adolescent experience of crisis (identity crisis) at the stage of transition from the teenage years to youthful age.

Finally, a special attention is paid to the analysis of the influence of school as a social institution that taboos manifestations of physical aggression. In this regard, adolescents' opinion about the teachers' reactions to fights between students is of particular interest.

\section{Discussion \\ 1. Fights}

The respondents were asked the following question: "Have you fought for the past two months?" The responses received show that more than a quarter of adolescents (28.1\%) have "participated" in fights. Almost the same number $(27.9 \%)$ stated that they "had not participated in fights" within this period of time. Finally, $44.1 \%$ chose the third option - "I don't fight at all".

Compared to girls, boys are much more likely to fight. So, whereas the statement "I don't fight at all" was chosen by more than half of the girls $(60.8 \%)$, the boys were only a quarter $-25.3 \%(p=.00001)$. The data, concerning the responds to another option - "participation in fights over the past two months", - show that the option was chosen by $43.4 \%$ of the boys and $14.3 \%$ of the girls $(p=.00001)$. Thus, the conclusion is clear: fights are much more common among boys than among girls. It is trivial in itself. Yet, it is the degree of prevalence of fights that is of interest. As the figures show, it is very high: almost every second boy and every seventh girl get involved in fights.

Focus on the age dynamics of participation in fights proves that the percentage of those who "do not fight at all" does not change with age among both boys and girls: $28.0 \%$ of the boys in Grade 7 and $23.3 \%$ of the boys in Grade 11 ; the percentage for girls is $65.4 \%$ and $62.6 \%$, respectively. At the same time, the percentage of boys who fight frequently ("participated in fights over the past two months") decreases sig- 
nificantly with age. The age dynamics of boys and girls who chose this option to answer is shown in Fig. 1.

These data provide the evidence of a consistent decrease in the percentage of boys, taking an active part in fights, with age. This tendency may indicate that at the stage of transition from teenage years to youthful age the male subculture is significantly transformed as per the prevalence of physical aggression. However, the percentage of frequent participants in fights in Grade 11 (at least once every two months) is very high and makes about one third. According to the diagram, there are no significant changes with age among the girls. Taking this into account, it is important to notice that in Grade 11 (when the actual adolescent stage would seem to have been overcome) about every tenth girl often participates in fights. We believe this is an extremely high percentage. As for the phenomenon of the prevalence of fights among the girls, it can be considered as a "new formation" of the female youth subculture.
Oddly enough, the parents' education level has almost no effect on the adolescents' participation in fights. It can only be noted that the girls with both parents' low level of education (that of vocational schools) are slightly more likely to participate in fights compared to those whose parents have higher education: they are $18.5 \%$ and $12.9 \%$ respectively $(p=.03)$. Comparison of the responses of adolescents from families with different financial status has not revealed any differences regarding their participation in fights. Thus, we can conclude that, in general, traditional socio-stratification differentiation (the level of parents' education, the financial position of the family) is not a significant factor that affects an adolescent's propensity to physical aggression.

Other points turn to be more significant. Comparison of the responses of the adolescents, who are prone to deviant behaviours such as alcohol and drug use, is of particular interest. Figure 2 shows the data concerning the participation in fights of the boys and girls who are actively involved in drinking vodka

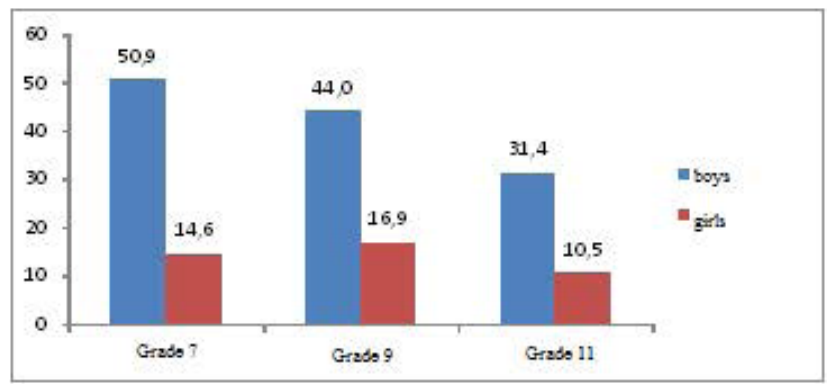

Fig. 1. Age dynamics of changes in the number of students who participated in fights over the past two months (\%)

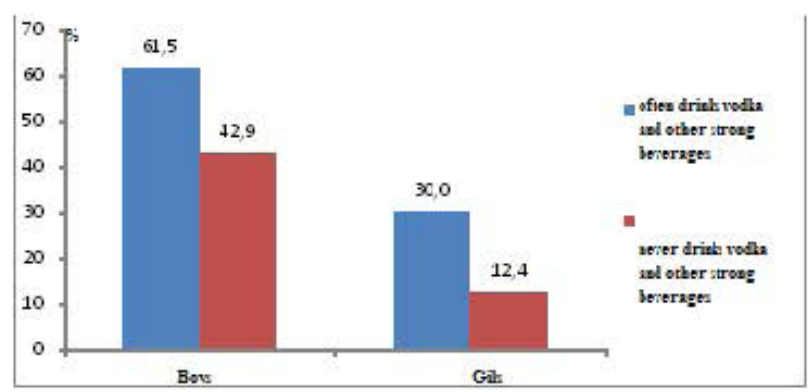

Fig. 2. Participation in fights over the past two months (the data concerning the adolescents who "often drink strong alcoholic beverages" and those who "never drink them") (\%) 
and other strong alcoholic beverages (once a week and more often) and those who do not drink strong alcoholic beverages.

The obtained materials indicate that an adolescent's involvement in the frequent use of strong alcoholic beverages clearly affects his/ her propensity for physical aggression.

A similar tendency has been revealed with regard to drug use. So, adolescents who use drugs are much more likely to get involved in fights. Whereas there are $63.6 \%$ of drug users who fought over the past two months, there are $27.6 \%$ of those who belong to this group among non-users $(\mathrm{p}=.00001)$. Accordingly, the percentage of those who "do not participate in fights at all" is significantly lower among drug users than among non-drug users: $12.1 \%$ and $44.4 \%(p=.0002)$.

In general, these data result in the conclusion about the link between various forms of deviant behaviour (alcohol, drugs, and fights). This can be viewed as a certain behavioral complex determining the "lifestyle" of a group of adolescents prone to deviation.

The issue of adolescents' participation in group fights is also of special interest. The responses show that one third of them $(32.0 \%)$ participate in fights of this kind. Their number is significantly higher among boys (38.1\%) than among girls $(20.5 \%)(p=.00001)$. This leads to the conclusion that this form of group aggression is more characteristic of the male adolescent subculture. We note that the percentage of girls participating in group fights is very high. It has already been mentioned above that mass prevalence of fights among girls is a fact of the adolescent subculture transformation of the 90s. In this regard, it should be emphasized that every fifth of those fighting adolescents takes part in group fights nowadays. We claim this is a completely new phenomenon of the female adolescent subculture, when belonging to a group (group identity) is a factor that causes the physical aggression manifestation in an adolescent girl.

When discussing an adolescent's involvement in group fights, it is important to note that in contrast to the question about the frequency of participation in fights there is almost no age dynamics (neither among boys nor among girls). In this regard, it can be concluded that this form of group aggression develops at the initial stages of adolescence already. This fact is important in the general context of problems related to the adolescents' social development. Indeed, since the key point at the stage of adolescence is the "expansion of social environment", it can be assumed that participation in group fights is due to the desire to maintain a group membership. In this respect, group identity is associated with a heightened perception of negative manifestations that are external to the group.

\section{Motivation for participating in fights}

Table 1 shows the results of the adolescents' responses to the question about the reasons for their involvement into fights.

The data shown in the table prove that the dominant motive for getting involved in fights is protection of the adolescent's own self. It is "reaction to an insult". In addition, the motives related either to the protection of group interests or to the reaction to an insult of a friend are also significant. In other words, these are reactions to aggression against individuals from the adolescent's microsocial environment. In fact, such motivations are associated with an attempt to morally justify their participation in fights. It is characteristic that almost every second adolescent explains his/her involvement into the fight as forced defense.

Another line of motivations is related to maintaining one's social status ("one's reputation support", "so they don't think I'm weak", "showing one's superiority").

And, finally, the fight acts as a means of either "release", "stress relief", or "appropriation of money, things" (these are already hooligan actions which are not hidden by the respondents). Such a line of motivations can be considered as an indicator of the obvious deformation of the moral sphere of an adolescent's personality.

Compared to girls, boys are more likely to give a variety of motivations that justify their involvement in fights. In principle, this indicates a more poly-motivated nature of their behaviour. It is also worth noting that, compared to boys, girls are more likely to get involved into 
Table 1. Motives for boys' and girls' involvement into fights (\% of those participating in fights)

\begin{tabular}{|l|c|c|c|}
\hline \multicolumn{1}{|c|}{ Motives } & boys & girls & $\mathrm{P}=$ \\
\hline I was offended & 73,7 & 65,6 & .002 \\
\hline My friend was offended & 45,0 & 34,1 & .0001 \\
\hline Jealousy & 6,9 & 11,0 & .01 \\
\hline I had to defend myself & 50,2 & 50,0 & - \\
\hline I had to stand up for a stranger & 7,7 & 4,4 & .004 \\
\hline So they don't think I'm weak & 8,2 & 5,4 & .04 \\
\hline I wanted to defend the group's point of view & 10,5 & 6,3 & .002 \\
\hline I lost self-control because of alcohol (drug) intoxication & 4,5 & 1,3 & .0002 \\
\hline For the purpose of appropriating money, things & 1,6 & 0,6 & - \\
\hline I wanted to show my superiority & 3,9 & 3,1 & - \\
\hline From boredom, bad mood & 8,4 & 8,5 & - \\
\hline My national and religious feelings were insulted & 12,0 & 7,1 & .004 \\
\hline I wanted to get emotional release, relieve tension & 7,7 & 10,2 & - \\
\hline I wanted to maintain my reputation in the eyes of others & 10,1 & 5,4 & .001 \\
\hline
\end{tabular}

fights "because of jealousy". $11.0 \%$ of the girls tend to indicate this motive, whereas such boys are $6.9 \%(p=.01)$. We argue that this difference is quite interesting in culturological terms. Indeed, in the male culture jealousy is evaluated as a characteristic feature humiliating personal dignity. A jealous man is a man who admits his weakness in front of others. He believes that a woman can abandon him in favor of another. Moreover, he is often endowed with such qualities as stupidity, impenetrability etc. This type of a jealous person is very common in works of art. Therefore, it is a shame to admit jealousy. Cases of describing a jealous person as a strong nature are extremely rare ("Othello"). A jealous woman is a different matter. This, on the contrary, usually manifests a strong nature fighting for her chosen one. Thus, these differences between boys and girls regarding their motivations for getting involved in fights can be explained by the influence of cultural norms and stereotypes regarding the resolution of interpersonal conflicts.

Analysis of the age dynamics of changes in motivation for getting involved in fights is of particular interest. There are fundamental differences between boys and girls here. So, whereas the girls' motivation structure remains almost invariant from Grade 7 to Grade 11, the boys have rather a complex age dynamics of changes in the significance of motives.

With this, the analysis of the motives for getting involved in fights among the boys reveals two stages.

At the first stage, with the transition from Grade 7 to Grade 9, there is a sharp increase in importance of such motives as "the desire to defend the group's point of view" (7.3\% and $11.7 \%$ respectively, $p=.03$ ); "the desire to maintain one's reputation and position among others" (from $7.0 \%$ to $13.1 \%, p=.009$ ). Both motives are obviously related to maintaining group membership. Thus, getting involved into fights because of an adolescent's desire for group identity is actualized precisely at the age stage of transition to early youth.

At the second stage (the transition from Grade 9 to Grade 11), the significance of the motive associated with "personal insults" is significantly reduced (from $76.4 \%$ to $67.1 \%$ respectively, $p=.02$ ). At the same time the importance of self-defense - "I had to defend myself" - increases (48.9\% and 56.9\% respectively, $\mathrm{p}=.05)$. The importance of the motive "I had to stand up for a stranger" is also growing (from $4.8 \%$ to $8.6 \%$ respectively, $\mathrm{p}=0.5$ ). It is clear that these content changes in motivation that determines getting involved into fights are 
radically different from the previous age stage. So, "personal insult" is less often a reason for participating in fights. It can be assumed that at this age the adolescents are already acting less impulsively in such situations and have developed culturally acceptable ways to resolve those conflicts that are associated with insulting a personality. Conflicts are increasingly resolved in a different way at least among the eleventh-graders. The fact that the students in Grade 11 have a stronger motive for "having to defend themselves", in our opinion, indicates an increase in the negative attitude to fights with age. It should be noted that for a number of other reasons the same tendency can be traced to justify the adolescents' getting involved into fights as a forced measure because of external reasons (for example, "I had to stand up for a stranger"). In principle, the growth of this kind of motivations by Grade 11 indicates that getting involved in fights is associated here with getting into new "unfamiliar" situations rather than with conflicts in a microsocial environment. To a certain extent, this can be linked to the problem of expanding an adolescent's social environment.

Besides age dynamics, it is of particular interest to compare the motives for getting involved into fights of adolescents from different social strata in terms of their material security. Analysis of the data shows that adolescents from low-income families are much more likely to participate in fights because of the desire to "defend their group's point of view" $(19.2 \%$ of adolescents from low-income families, $8.2 \%$ - from the middle-income families, $\mathrm{p}=.005$ ). Another motive that is more often noted by adolescents from low-income families is "for the purpose of appropriating money, things" $(3.9 \%$ of adolescents from low-income families, $0.9 \%$ - from the middle-income families). And, finally, for adolescents from low-income families, it is more typical to get involved into a fight "because of boredom, bad mood" (13.5\% of adolescents from low-income families, $4.6 \%$ - from the middle-income families, $\mathrm{p}=.03$ ).

The motivations mentioned above characterize a special style of behaviour of an adolescent from a low-income family. This is an obvious sign of his/her social disadvantage. An adolescent from a weak social stratum not only enters a fight "because of boredom" or "bad mood" and looking for a sort of "entertainment" (others are apparently not available), but also because of selfish reasons ("appropriation of money, things") which, in fact, entail criminal liability. At the same time, it is also characteristic that the motivation "I wanted to defend the group's point of view" is clearly expressed among the adolescents from low-income families. All this gives reason to believe that these are group associations of adolescents from low-income social strata that are a dangerous, criminal zone that cultivates aggressive and hooligan behaviours.

For children from high-income families motivation for getting involved into fights has different grounds. Thus, adolescents from such families are significantly more likely to have such motives as "insult to their personal dignity" $(77.7 \%$ of adolescents from high-income families and $69.7 \%$ - from medium-income ones, $\mathrm{p}=.03$ ); "insult to their friend's personal dignity" (48.6\% and $40.3 \%$ respectively, $\mathrm{p}=.02)$; "jealousy" (13.7\% and $7.6 \%$ respectively, $\mathrm{p}=.009$ ).

It is obvious that, in contrast to the motivations of adolescents from low-income families, the students from high-income families generally motivate their fights as the desire to preserve both their own personal dignity and their friends' dignity (thereby emphasizing the importance of their microsocial environment). This is due to the protection of their selves. It is orientation towards preservation of personal dignity that makes their involvement into fights different. It is important to attribute the heightened sensitivity to personal dignity, since this may be due to certain moral and ethical principles of behaviour - "codes of honour", characteristic of the adolescent subculture.

Thus, in the course of analyzing motivation, that determines the adolescents' participation in fights, the influence of different value orientations differentiating social strata is also manifested in a peculiar way.

Finally, it is worth while focusing on analyzing the responses of those students who do not take part in fights. Below is the description 
of their justification of refusals to participate in fights.

The obtained data show that the responses are dominated by two motives: "I sort things out in a different way" (67.3\%) and "It is beneath my dignity" (13.2\%). The rest of the motivations suggested ("This is against my moral principles", "It is not customary among my friends", "I'm scared of getting or causing injury", "It will damage the reputation", "It is the fear of consequences") are extremely rare.

Analysis of gender differences indicates that, compared to boys, girls are more likely to note both motives when justifying their refusal to get involved in fights. Boys are a little more likely to name a motive associated with "the fear of consequences and revenge" (5.2\% of boys and $1.6 \%$ of girls respectively, $\mathrm{p}=.001$ ). This indicates that conflict relationships in the male subculture are more often controlled by the adolescents' group communities. This leads to their longer and more protracted character.

In general, a detailed analysis of the obtained data shows that, in contrast to the motivation for getting involved into fights, the significance of the reasons for refusals to fight does not change fundamentally with age for both boys and girls. There are not any significant differences between students from different social strata either. So, we conclude that the motivation that ensures maintaining the norm of the ban on participation in fights is culturally invariant and practically does not change throughout adolescence and early youth. Thus, the very structure of motivation that ensures the rejection of manifestations of physical aggression (i.e., its "blocking") is formed at earlier age stages. We claim that it is extremely important to take this into account when developing psychological and pedagogical programmes aimed at correcting deviant behaviours.

\section{Manifestation of physical aggression in school}

To identify the prevalence of fights on school grounds, adolescents were asked a special question: "Have you ever fought on school grounds for the past two months?" $29.9 \%$ of the respondents gave an affirmative answer ("yes"). Moreover, additional analysis shows that of all the adolescents who have ever participated in fights for the last two months half of them (51.1\%) fought on the school grounds. In other words, the number of those who fight in school is almost the same as the number of those who fight outside its walls. Thus, we can conclude that school today is not a social space where the manifestation of physical aggression among adolescents is really taboo.

Boys participate in fights on school grounds much more often than girls $(36.1 \%$ and $18.6 \%$ respectively, $p=.00001)$. So, the percentage of girls who fight on school grounds is significantly lower than that of boys. Thus, it can be concluded that girls are more likely to obey the rules of school behaviour.

While discussing the age aspect, it is important to pay attention to the fact that students of older age groups (eleventh graders) are significantly less likely to participate in fights on school grounds. A special analysis of the data shows that among the boys, who fought in the course of the past two months, the majority of the seventh-graders fought on the school grounds $-66.7 \%$; among the ninth-graders there are half of them $-55.8 \%$; among the eleventh-graders there are a third of them $-30.2 \%$. Thus, whereas it is school where the majority of young adolescent students resolve conflicts through physical aggression (they mostly fight in school), it is no longer the main place for physical aggression for the eleventh grade boys. Senior adolescent students, as a rule, fight outside school, this being a specific reflection of the phenomenon of "the social environment expansion". A decrease in fights between senior school students, in particular, can be also explained by the change of the student's social status in the social space of school with age. So, with his/her transition to senior grades a senior student who is much older (and, consequently, has a higher social status in school environment) can no longer fight with the younger ones, since this way of resolving the conflict is considered a clear decrease in his age-related social role position.

It is characteristic that the same age tendency regarding the students' participation in fights on school grounds is also observed among girls: in Grade 7, 55.6\% of fighting 
girls state that they fight in school; in Grade 9 , they are $39.2 \%$, and in Grade 11, they are $26.2 \%$.

Besides age dynamics, there has been revealed a special influence of social stratification factors. Thus, whereas $30.0 \%$ of students from low-income families fight on school grounds, their number is significantly greater among students from high-income families (45.2\%). Such social-stratification differences can be interpreted in two ways. On the one hand, this fact gives grounds for the conclusion that students from high-income families feel much freer in the walls of the school and they are less influenced by the current school norm of the ban on physical aggression (in other words, "these rules are not for them"). On the other hand, it is necessary to correlate these data with the above-mentioned features of motivation that encourages the adolescents to get involved into fights. It should be recalled that a distinctive characteristic feature of the motives for the adolescents from high-income families to participate in fights are those of personal nature ("insulting one's personality", "insulting friends", and "jealousy"). In this regard, we can assume that social environment in school is personally more important for these adolescents, and that is why they are forced to react to their school peers' attitude more sharply. As we have shown above, the motive "the desire to defend the group's point of view" was much more significant for the adolescents from low-income families. Thus, since students from low-income families are less likely to participate in fights on school grounds, it can be concluded that school mates is not a significant group for them. These are others "outside school" who are of significance.

Finally, the students' opinions on their teachers' reaction to fights on school grounds are of particular interest. Every fourth adolescent $(22.5 \%)$ believes that the teachers "generally do not know anything about fights in school". Just over half of them $(58.3 \%)$ think that teachers "know about some fights but do not know the reasons". Every fifth (19.2\%) assumes that teachers are well aware of fights: "they know about fights and the reasons causing them".
Comparison of the boys' and girls' responses shows that the percentage of those who believe that teachers are aware of the students' fights is significantly higher among the girls. So, whereas the percentage of those girls who believe that "teachers do not know anything about fights" is $14.1 \%$, the percentage of boys who think so is $31.7 \%(p=.00001)$. It is characteristic that the percentage of those who believe that teachers are aware of not only fights, but also of their reasons decreases significantly as the students (both boys and girls) get older. The sharpest decline in the percentage of those with the same opinion is characteristic of the period between Grade 7 and Grade 9: 26.1\% and $16.6 \%$ respectively $(p=.00001)$. This allows us to conclude that with the transition to senior school the students view their life at school and their relations with peers as more "closed" from teachers. In other words, in the course of transition to senior school the social space of communication with peers is built and evaluated by adolescents as "intimate".

Besides the question about the teachers' awareness of fights on school grounds, the survey also revealed the students' opinions about the teachers' reactions to fights. From the students' point view, the most common reaction of a teacher to fights between students is "reprimands" (34.7\%), "calling parents to school" $(25.2 \%)$, and "calling to the headmaster" $(15.6 \%)$. Other types of teachers' reactions to school fights were noted by a small number of the respondents.

Analysis of the age dynamics shows that the main changes in the evaluation of the teachers' reactions to fights are noticed within the period between Grade 7 and Grade 9. At the same time, the frequency of mentioning such forms of the teachers' reactions as "reprimands" (41.5\% for the seventh graders; $29.4 \%$ for the ninth graders; $p=.00001$ ) and "reprimands to the whole class" $(6.6 \%$ and $3.1 \%$ respectively; $\mathrm{p}=.00001)$ is reduced. In parallel, the teachers' focus on the use of the administrative measures of influence increases: "calling to the headmaster" ( $10.9 \%$ and $17.8 \%$ respectively; $p=.00001)$, "calling to pedsovet (teachers' council)" (1.5\% and $3.9 \%$ respectively; $p=.009$ ). We argue that these changes between Grade 7 and Grade 9 
are very significant. Thus, whereas the teacher tends to take personal responsibility for resolving conflicts between seventh graders and to involve the whole class as a team (the teacher reprimands personally, organizes meetings, etc.), he/she is more focused on administrative measures of influence with the senior students. Basically, this orientation of the teacher towards administrative measures of influence does not change at a later age stage (from Grade 9 to Grade 11).

We claim that this line of changes in the teacher's behaviour strategy regarding fights among students of different age groups characterizes the uniqueness of school as a social institution. So, at the junior school level, it is the teacher who plays a crucial role in resolving conflicts between students that were caused by fights. He/she takes the function of control and imposing sanctions while relying on the opinion of the children's team and purposefully forms this opinion (the pedagogical principle of "educating role of the children's team" is well known). At the senior school level, control and sanctions related to violations of norms are transferred to higher levels in the hierarchy of school management (teachers' councils, directorate). In other words, the change in the student's age position within his/her school years, as we can see, is also associated with a change in his/her social position, since the sanctions of higher structures in the management of school as a social organization turn to be more significant.

We consider that when determining the sanctions related to physical aggression the revealed tendency, that detects the interconnection of the student's social and age status with the hierarchy of school management levels, should be given a special analysis in the course of developing correctional educational programmes. At that the range of problems related to school self-government issues apparently becomes important.

\section{Conclusion}

The following three points seem to be important to note:

1) The survey materials have revealed an extremely high degree of prevalence of physi- cal aggression in adolescent environment. This is due to both social mechanisms of the adolescent subculture functioning and mental characteristic features of adolescence. The connection between the adolescents' involvement in fights with other deviant forms of behaviour is necessary to pay attention to, since it indicates the formation of special styles of deviant behaviour at this age. These styles act as social models that determine the specific lines of the adolescents' socialization. The prevalence of fights among girls is of particular concern, the fact indicating a significant deformation of gender-role behaviours in the adolescent subculture.

2) The obtained materials on the motives of participation in fights have made it possible to reveal the complex age dynamics of the adolescent's emotions towards various aspects of the emerging conception of the self (insult, humiliation, jealousy, group identity, etc.). In this regard, psychological defense mechanisms which are associated with the adolescent's relationships with his/her social environment are very clearly manifested. Gender differences and age-related transformations of the motives by which the adolescents explain their participation in fights are extremely important, since, according to the materials obtained, the complex dynamics of actualization of different levels of the conception of the self is manifested here: the ideal self, the real self and social identity.

3) Materials on the prevalence of fights between adolescents in school resulted in identification of a number of important points that characterize the school as a social organization. Age, gender, and social stratification factors have their significant effect here. It should be emphasized that with the students' transition to older age groups they themselves evaluate the space of social relations between peers as increasingly closed from the teachers. As for the school norms, they are considered as external and formal regarding the realities of social relations within a group of students. The analysis of age characteristics of the students' participation in fights has revealed a link between the age status and the sanctions applied to the students by different levels of school manage- 
ment: the rules being violated and the students growing older, the teacher is more likely to shift his/her responsibility to higher administrative levels of management.

\section{References}

Bandura, A., Uoters, R. (2000). Podrostkovaia agressiia. Izuchenie vliianiia vospitaniia i semeinykh otnoshenii [Teenage aggression. Exploring the influence of upbringing and family relations]. Moscow, Aprel' Press, 508 p.

Baryshnikova, L.M. (2012). Gendernye razlichiia v proiavlenii agressii podrostkov [Gender differences in display of teenage aggression]. In Igosheva, B.M., Larionova, I.A., Slavina, A.S (eds.) Aktual'nye voprosy razvitiia sotsial'noi aktivnosti molodezhi v Ural'skom federal'nom okruge. Vospitanie sotsial'no aktivnoi molodezhi v raznovozrastnykh detsko-iunosheskikh kollektivakh po Materialam IV Vserossiiskikh sotsial'no-pedagogicheskikh chtenii im. B.I. Livshitsa [Topical issues of developing youth social activity in the Ural Federal District. Education of socially active youth in mixed age groups: Proceedings of IV All-Russian social-and-pedagogical conference named after B.I. Livshits], 45-54.

Chepeleva, L.M. (2002). Reshenie problemy agressivnosti podrostkov v shkole pedagogicheskoi podderzhki [Solving the problem of teenage aggression in the school of pedagogical support]. Krasnodar, Prosveshchenie-Iug, $64 \mathrm{p}$.

Dashieva, S.V., Budaeva, S.D. (2019). Razrabotka programmy profilaktiki agressivnogo povedeniia podrostkov [Development of the preventive programme of aggressive teenagers' behavior]. In Nauchnyi al'manakh [Scientific almanac], 3-2 (53), 128-132.

Feshbach, S. (1971). Dynamics and morality of violence and aggression: some psychological considerations. In American Psychologist, 26, 281-292.

Green, R.G., Donnerstein, E.I. (eds) (1983). Aggression. Theoretical and Empirical Reviews. Vol. 1-2. Theoretical and Methodological Issues. New York, Academic Press, 209 p.

Koloiartseva, L.A. (2016). Uroven' agressivnosti u podrostkov s vysokim sotsiometricheskim statusom $\mathrm{v}$ klassakh, razlichaiushchikhsia po vneshnemu proiavleniiu agressii [The level of aggression of teenagers with high socio-metric status in classes showing different manifestations of aggression]. In Nauchnaia initsiativa v psikhologii: mezhvuzovskii sbornik nauchnykh trudov studentov i molodykh uchenykh [Scientific initiative in psychology: collection of students' and young scientists' works]. Kursk, 50-54.

Kon, I.S. (1979). Psikhologiia iunosheskogo vozrasta: Problemy formirovaniia lichnosti [Psychology of youth. Problems of personality formation]. Moscow, Prosveshchenie, $175 \mathrm{p}$.

Lebedeva, E.V. (2019). Agressiia i vrazhdebnost' v mladshem podrostkovom vozraste [Aggression and hostility in early teens]. In Nauchnyi aspekt [Scientific aspect], 2, 2, 157-162.

Lipskaia, L.A. (2019). Faktory rasprostraneniia destruktivnogo povedeniia v podrostkovoi srede [Factors of spreading the destructive behavior in adolescence]. In Sotsium i vlast' [Society and governance], 1 (75), 53-59.

Mantrova, M.S., Skakun, E.V. (2015). Problema izucheniia proiavlenii agressii v povedenii podrostkov, obuchaiushchikhsia $\mathrm{v}$ gorodskikh i sel'skikh shkolakh [The problem of exploring aggression in teenagers' behavior in urban and rural schools]. In Nauka segodnia: teoreticheskie i prakticheskie aspekty. Sbornik nauchnykh trudov po materialam mezhdunarodnoi nauchno-prakticheskoi konferentsii: $v 3$ chastiakh [Proceedings of International scientific and practical conference "Science today: theoretical and practical aspects", in 3 vol.]. Nauchnyi tsentr "Disput", 129-130.

Sheveleva, O.A. (2006). Sotsial'no-psikhologicheskie aspekty gruppovoi agressii podrostkov [Social and psychological aspects of teenagers' group aggression]. In Sovremennye gumanitarnye issledovaniia [Modern humanitarian researches], 2 (9), 241-242.

Slovák, P. (2015). Genesis aggression and search for the good in adolescents. In Natsional'naia Assotsiatsiia Uchenykh, 15-1 (15), 55-57.

Sobkin, V.S., Fedotova, A.V. (2019a). Podrostkovaia agressiia v sotsial'nykh setiakh: vospriiatie i lichnyi opyt [Adolescent aggression in social media: perception and social experience]. In Psikhologicheskaia nauka i obrazovanie [Psychological Science and Education], 24, 2, 5-18. 
Sobkin, V.S., Fedotova, A.V. (2019b). Teenagers in social networks: patterns of usage and aggressiveness. In J. Sib. Fed. Univ. Humanit. soc. sci., 12 (9), 1733-1752.

Sobkin, V.S., Fomichenko, A.S. (2011). O situatsiiakh agressivnogo povedeniia mezhdu uchenikami (po materialam kontent-analiza uchitel'skikh sochinenii) [On the situations of students' aggressive interaction (based on the content-analysis of teachers' essays)]. In Sotsiologiia obrazovaniia. Trudy po sotsiologii obrazovaniia. [Sociology of education. Works on the sociology of education], 15 (26), 177-204.

Sobkin, V.S., Fomichenko, A.S. (2012a). Ponimanie uchiteliami prichin proiavleniia agressii uchashchikhsia k pedagogu [Teachers' understanding of students' aggression]. In Sotsiologiia obrazovaniia. Trudy po sotsiologii obrazovaniia [Sociology of education. Works on sociology of education], 16 (28), 137-147.

Sobkin, V.S., Fomichenko, A.S. (2012b). Agressivnost' shkol'nikov glazami uchitelei [Teachers' understanding of students' aggression]. In Direktor shkoly [The Headmaster], 5, 84-90.

Tedeschi, J.T., Smith, B.R., \& Brown, R.C. (1974). A reinterpretation of research on aggression, In Psychological Bulletin, 81 (9), 540-562.

Zhmurov, D.V. (2007). Stsenarnaia agressiia podrostkov [Scenario aggression of teenagers]. In "Chernye dyry" $v$ Rossiiskom zakonodatel'stve: Iuridicheskii zhurnal ["Black holes" in Russian law: Law journal], 6, 461-462. 


\title{
Проявления агрессии в подростковой среде
}

\author{
В.С. Собкин, Е.А. Калашникова, А.В. Федотова \\ Центр соииологии образования \\ Институт управления образованием Российской академии образования \\ Российская Федерация, Москва
}

\begin{abstract}
Аннотация. В статье рассматриваются особенности проявлений физической агрессии среди подростков и основные мотивы, побуждающие подростков прибегать к насилию. В основу статьи легли материалы, полученные сотрудниками Центра социологии образования «Института управления образованием Российской академии образования» в ходе анонимного анкетного опроса 2983 учащихся 7, 9 и 11 классов московских школ.

В ходе анализа влияния гендерных, возрастных и социально-стратификационных факторов выделены мотивационные доминанты, определяющие особенности участия подростков в драках в зависимости от пола и возраста.

Особое внимание уделяется рассмотрению проявлений физической агрессии в стенах образовательной организации, а именно распространенности драк на территории школы и мнениям учащихся о реакции их учителей на возникающие между подростками драки.

Достаточно высокий уровень распространенности драк среди девочек свидетельствует о существенной деформации традиционных полоролевых моделей поведения в подростковой субкультуре.

Полученные результаты позволяют сделать вывод о том, что проявления физической агрессии связаны как с социальными механизмами функционирования подростковой субкультуры, так и с психическими особенностями подросткового возраста.
\end{abstract}

Ключевые слова: физическая агрессия, подросток, социализация, мотивация участия в драках, гендерная специфика, социально-стратификационные факторы, школа как социальный институт.

Научная специальность: 22.00.00 - социологические науки. 